\title{
The Growth of Eyelashes and Wigs Industries: Is it True that Working Mother Parenting Practice Affects Children's Social and Social Development
}

\author{
Asih Nur Ismiatun, Yoyon Suryono \\ Yogyakarta State University, Yogyakarta, Indonesia \\ e-mail: asih.nur2016@ student.uny.ac.id
}

\begin{abstract}
The growth of eyelashes and wigs industries have reached dozens of companies in Purbalingga District. The company has recruited thousands of female laborers, and there were many mother who has early age child among them. It was worrying that the less interaction between mother and children caused unoptimal children social development. The study involved 54 working mothers of 5-6 years old children in the Purbalingga District. This study analyzed the relationship between working mother parenting practice and children's social development. The research data was collected by distributing questionnaires about working mother parenting practice and children's social development. The instruments had been validated. The result of research indicated that there was no significant correlation between working mother parenting practice and children social development. A discussion regarding the current findings notify that good social development for children is formed not only because of mother's parenting but rather cooperative interaction between parents.
\end{abstract}

Keywords: growth of industries, working mother parenting, social development

\section{INTRODUCTION}

The growth of eyelashes and wigs industries have occurred since 1976, beginning when an investor from South Korea established a eyelashes and wigs hair company in Purbalingga District (Stacia and Gunanto, 2014). Until 2017 based on data from statistical agencies of major manufacturing directories in Central Java it can be seen that the number of companies reached the number 49 companies in 2015 and rose to 52 companies of eyelashes and wigs in 2016 covering both medium and large companies that have been recruted thousands of workers. The statistical data of Purbalingga District in 2017 collected data that $30 \%$ of the total laborer is in the industry sector, with $69.56 \%$ being female labor with the assumption that the most sector is in the area of eyelashes and wigs industries spreading all the way to the countryside.
That number shows that many women in Purbalingga District become a worker. The large number of women who work indicated that there were mothers who also work as labor. Although, there was no previous research on the exact numbers that indicated how many of women who have become mothers who also work in the eyelashes and wigs hair company.

The needs of economic has made many mother go to work and leave their children. Study of Ering, Akpan, \& Echiegu (2014) told that increasing in the number of working mothers with many requirements from their workplace are affecting the development of their children. After reviewing the factors mentioned in the introduction, the researcher finds a need to conduct a research that addresses these issues. Therefore, the purpose of the study is to examine the relationship between working mother 
parenting practice and children's social development.

\section{LITERATURE REVIEW}

\subsection{Working Mother Parenting Practice}

Mothers have a lot to do in the area of proper child care and development (Geoffrey L. B. et al., 2011).The time spent on a working mother indicated that a mother can not interact all day with the child and indicated that mother did less optimal parenting to the child compared with a mother who is not working. Mothers play vital role in the nurturing of their children for a proper and appropriate child development and up bringing; child development therefore is the positive change which occurs in the life of a child (Mensah \& Luranchie, 2013). Another theory explains that a mother is more likely to have a managerial role in parenting than father, which is primarily in the child's social development (such as arrangements on the child's opportunity to engage in social contact with peers or adults, effective monitoring of the child on social premises , activities, and interaction with their friends (Santrock, 2007: 164).

Require women to leave their household, thus significantly and directly impacting on family life (McKie and Callan, 2012: 194). Based on prevoius research on the comparison between mothers working with housewives (not working mother) explained that working mothers tend to have worse parenting qualities than not working mother (Shpancer et al., 2006). Based on the results of interviews with the community around the research taken place, they assume that when children have bad behavior is the result of unoptimal mother's parenting practice, moreover, if the mother has a job, where they can not controling their child's behaviour every day.

A study also revealed that working mothers applied discipline to deal with their children, because that discipline is considered an effective way for working mothers to manage their children, their families and responsibilities, and even working mothers can also apply physical punishments such as anger and slap their children when children showing bad behaviour or if their children do not follow the rules of discipline rules (Sultana et al., 2013). Indeed, a working mother should balance this double role well because how a mother is able to portray this dual role will determine the quality of family life and can predict their parenting pattern (Chang and Kim, 2016). A regularly-applied parenting practices can facilitate the development of children's prosocial behaviors. (Carlo, McGinley, Hayes, Batenhorst, \& Wilkinson, 2007)

The working conditions of the mother may affect the child's development indirectly through its influence on the parenting style or other aspects of the family process. The less time left for family communication because of the time spent working can also cause stress (Berns, 2011: 108).. Working many hours or experiencing a negative workplace atmosphere is associated with reduced parental sensitivity, fewer joint paret-child activities, and poores cognitive development throughout childhood and adolescence (Brooks, 2011). Negative interaction in the work will affect the parent's interaction with the child and can lead working mother who have preschoolers who got experience stress in work tend to withdraw and less attention, less caring, and less warm when they pick up their children (Brooks, 2011: 706). Another impact is that working mothers encourage children to be independent so that their children can do everything from themselves (Sultana \& Noor, 2012).

\subsection{Children Social Development}

Social development is the acquisition of the ability to behave in accordance with social demands Hurlock (1978: 250). Social development requires a person to be able to socialize or live in society. This ability must be developed from an early age where children are also like other human beings who are social beings. Children, like other humans are social being. As they grow and develop the form relationship and socialized with others. Socialization is the process influenced by parents and others to ensure that children learn the standards of behaviour, attitudes, and skills associated with the society or cultiure in which they develop (Marion, 2015: 145). The basis of socialization lies in interaction. Interaction can be consideres a proces in and of itself (Ahola, 2007). The pattern of social development is a change and stability in emotions, personalities, and social relations together can form a change in emotion, personality and social relations (Papalia, et al., 2008: 12).

Social development in early childhood includes the task of a child to be able to show prosocial behavior. The early development of children's prosocial behaviors, such as helping and 
sharing are important skills for building positive social relationships later on (Spinrad, Eisenberg, and Fabes, 2006). Prosocial behavior in children's social development includes three indicators, that are sharing, helping, and cooperative attitude (Marion, 2015: 75-76). Based on Regulation of the Minister of education and culture No. 1372014 about Standard Level Achievement of Child Development, children social development is divided into three types of behavior that is self-awareness, responsibility and behavior prosocial.

The behavior of sharing with peers appears in children aged 5-6 years old Parke and (Stewart, 2011: 251). Endedijk, et al (2014) said that cooperation relates to individual differences related to the characteristics of children's temperament, and successful cooperation with peers will increase with age Helping involves performing simple everyday acts of kindnessand recue and it lso includes defending others (Marion,2015:75).

The early development of child prosocial behavior occurs in the context of family and it is potentially influenced by the process of interaction within the family family (Scrimgeour, Blandón, Stifter, \& Buss, 2013). The first pattern of social behavior in the family, good or bad behavior that children show in interacting with peers is the result of the social relationships that children acquire within the family, which is a direct influence of the parental style of education (Blaževi, 2016).

\subsection{Material \& Methodology}

\subsubsection{Participant}

Participant in this study included 54 mothers who worked in the eyelashes and wigs companies in Purbalingga District. Working mother is a mother who has children aged 5-6 years old. Participant selected randomly in the area Purbalingga.

\subsubsection{Development of the Instrument}

The research instrument is based on collected theories. The instrument consisted of two research questionnaires about working mother parenting practice and social development of children aged 5-6 years old. Working mother parenting practice instruments measure the indicatorsof time of togetherness with children, the quality of parenting, the application of discipline, and the application of punishment. Social development instrument of children aged 5-6 years measure indicators of shared behavior, sympathy and cooperative behavior. Each instrument used favorable and unfavorable principles. The instrument is tested to 30 working mothers first to obtain valid and invalid items.

\subsubsection{Working mother parenting practice instrument}

Instruments for working mother parenting practice contains 25 items of questionnaires measure time of togetherness with children, the quality of parenting, the application of discipline, and the application of punishment. Measurement scale using Likert scale with five alternative answers with scores from 1 up to interval 4. The answer of each instrument item using Likert scale has gradation from very positive to very negative symbolized by number 1 (never), 2 (sometimes ), 3 (Frequency) and up to 4 (always). The results of the validity and reliability test of the maternal care instrument that works can be seen in the table 1 . Reliability test obtained by alpha cronbach coefficient of 0.870 .

\subsubsection{Children's social development instrument}

Instruments for social development of children aged 5-6 years contains 24 items of questionnaires to measure social development indicators of children, namely self-awareness, responsibility and prosocial attitude (sharing, mutual help, and cooperative). Measurement scale using Likert scale with five alternative answers with scores from 1 up to interval 4 (number 1 (never), 2 (sometimes), 3 (frequently) and up to 4 (always)) Test results validity of social learning viewed on the table 2 .Conbach reliability test obtained coefficient alpha cronbach of 0.899 .

Table 1. The result of validity of working mother parenting practice instruments

\begin{tabular}{|c|c|c|c|c|c|}
\hline \multirow{2}{*}{ No } & \multirow{2}{*}{ Indicators } & \multirow{2}{*}{$\begin{array}{l}\text { Number } \\
\text { of items } \\
\text { before } \\
\text { vlidation }\end{array}$} & \multirow{2}{*}{$\sum$} & \multicolumn{2}{|c|}{$\begin{array}{l}\text { Number of items } \\
\text { after validation }\end{array}$} \\
\hline & & & & $\begin{array}{l}\text { Valid } \\
\text { items }\end{array}$ & $\begin{array}{c}\text { Invalid } \\
\text { items }\end{array}$ \\
\hline 1. & $\begin{array}{l}\text { Time of } \\
\text { togetherness } \\
\text { with children }\end{array}$ & $1,4,8$ & 3 & 1,8 & 4 \\
\hline 2. & $\begin{array}{l}\text { The quality of } \\
\text { parenting }\end{array}$ & $\begin{array}{c}2,3,5,6 \\
10,13 \\
14,15 \\
16,19 \\
21,24\end{array}$ & 12 & $\begin{array}{c}2,3,5, \\
6,10, \\
13,14, \\
15,16, \\
19,21, \\
24\end{array}$ & - \\
\hline 3. & $\begin{array}{l}\text { The } \\
\text { application of } \\
\text { discipline }\end{array}$ & $\begin{array}{c}7,12,18 \\
22,25\end{array}$ & 5 & $\begin{array}{l}7,12 \\
25\end{array}$ & 18,22 \\
\hline 4. & $\begin{array}{l}\text { The } \\
\text { application of } \\
\text { punishment }\end{array}$ & $\begin{array}{c}9,11,17, \\
20,23\end{array}$ & 5 & $\begin{array}{c}9,11, \\
17,20, \\
23\end{array}$ & - \\
\hline & Total & & 25 & & 22 \\
\hline
\end{tabular}


Table 2. The result of validity of social development instruments

\begin{tabular}{|c|c|c|c|c|c|}
\hline \multirow{2}{*}{ No } & \multirow{2}{*}{ Indicators } & \multirow{2}{*}{$\begin{array}{c}\text { Noumber } \\
\text { of items } \\
\text { before } \\
\text { validation }\end{array}$} & \multirow{2}{*}{$\sum$} & \multicolumn{2}{|c|}{$\begin{array}{l}\text { Number of item } \\
\text { after validation }\end{array}$} \\
\hline & & & & $\begin{array}{l}\text { Valid } \\
\text { item }\end{array}$ & $\begin{array}{c}\text { Invalid } \\
\text { item }\end{array}$ \\
\hline 1. & Sharing & $\begin{array}{c}1,2,5,10 \\
14,23\end{array}$ & 6 & $\begin{array}{c}1,2,5 \\
10,14 \\
23\end{array}$ & - \\
\hline 2. & Sympathy & $\begin{array}{l}3,6,7,11, \\
12,13,20\end{array}$ & 7 & $\begin{array}{c}6,7,11, \\
12,13, \\
20\end{array}$ & 3 \\
\hline 3. & Cooperative & $\begin{array}{c}4,8,9,15 \\
16,17,18 \\
19,21,22, \\
24\end{array}$ & 11 & $\begin{array}{c}4,8,15, \\
16,17, \\
18,19, \\
21,22\end{array}$ & $4,9,24$ \\
\hline & Total & & 24 & & 20 \\
\hline
\end{tabular}

\subsection{Procedure}

The 60 questionnaires were distributed in the study to working mothers with children of 5-6 years. In the questionnaire with permission application and explained the purpose of the study. However, after the final time 54 questionnaires collected from the participant.

\subsection{Measure}

The data collected for the current study was analysed using the IBM SPSS 22.0 for windows to analyze all instrument scores. Descriptive analysis, correlation analysis and ANOVA were used to answer the research questions of the relationship between working mother parenting practice and the social development children aged 5-6 years.

\section{RESULT AND DISCUSSION}

\subsection{Participant profile}

The study also collected mother's age data as participants and genre of the child. The following data can be seen in the table 3 . The contribution of mother's age to work and the genre of the child is also calculated. Based on the analysis, age $\mathrm{F}(3.18)=$ $0.534, \mathrm{p}=0.590(>0.05)$, and gender $\mathrm{F}(4.03)=$ $2.760, p=0.103(>, 05)$. mother care work and social development of children.
Table 3. Mean of mother's age, child's genre and the contribution of it

\begin{tabular}{|c|c|c|c|c|}
\hline Ages & Frekuensi & $\begin{array}{l}\text { Persentas } \\
\text { e }(\%)\end{array}$ & $\begin{array}{l}\text { Dummy } \\
\text { Test }\end{array}$ & \\
\hline & & & Ages & Genre \\
\hline $23-30$ & 27 & $50 \%$ & $\mathrm{~F}=0,534$ & \\
\hline $31-38$ & 20 & $37 \%$ & $\mathrm{P}=0,590$ & \\
\hline $39-46$ & 7 & $13 \%$ & $\mathrm{R}^{2=} 143$ & \\
\hline Mean & 31,34 & & & \\
\hline Genre & & & & $F=2,760$ \\
\hline Gir & 31 & $57 \%$ & & $\mathrm{P}=0,103$ \\
\hline 1 & & & & \\
\hline Boy & 23 & $43 \%$ & & $\mathrm{R}^{2=} 224$ \\
\hline
\end{tabular}

\subsection{Descriptive analysis}

Descriptive statistics in table 4 show the mean, median, mode, std. deviation, range, variance, minimum value, and maximum value of working mother parenting practice and social development of children aged 5-6 years.

Table 4. Descriptive analysis of working mother parenting practice and social development instruments

\begin{tabular}{lll}
\hline & Descriptive analysis \\
\hline Result & $\begin{array}{l}\text { working mother } \\
\text { parenting practice }\end{array}$ & $\begin{array}{l}\text { Social } \\
\text { development }\end{array}$ \\
\hline Mean & 39.63 & 53.69 \\
Median & 40.00 & 54.00 \\
Modus & 40 & 46 \\
Standard & 0.548 & 0.911 \\
deviation & & \\
Variance & 16.238 & 44.824 \\
Range & 20 & 42 \\
Minimum & 30 & 42 \\
score & & 77 \\
Maximum & 50 & \\
score & & \\
\hline
\end{tabular}

\subsection{Correlation between working mother parenting practice and social development}

The relationship between working mother parenting practice and child's social development was analyzed using pearson correlation (Table 5). The result shows the correlation coefficient shows the negative number $r=-0.168$. This means that the direction of the relationship between the two variables is not unidirectional and the two variables have a very weak or insignificant relationship. It is also indicated by the significance number $p=0.224$ (>0.05) . It does mean that if the working mother parenting practice score is high, the child's social development score will be low, and if the mother's 
care score is low, the child's social development score will be high.

Table 5. Pearson Correlation of working mother parenting practice and child's social development

\begin{tabular}{llll} 
practice and child's social development & & \\
& $\begin{array}{l}\text { Pearson } \\
\text { Correlation }\end{array}$ & $\mathrm{p}$ & $\mathrm{N}$ \\
\hline $\begin{array}{l}\text { working mother } \\
\text { parenting practice and } \\
\text { child's social } \\
\text { development }\end{array}$ & -0.168 & 0.224 & 54 \\
\hline
\end{tabular}

Based on the results of regression analysis showed that the coefficient of correlation coefficient simultaneously $r=0.168$. that figure illustrates the strength of the relationship between work mother $(\mathrm{X})$ and the social development of children aged 5-6 years (Y). Coefficient of determination $R^{2}=0028$. These figures show that the contribution of working mother parenting practice only $2.8 \%$ in the social development of children. While the remaining $97.2 \%$ is a contribution of factors other than the factors represented by the independent variables in this study.

Analysis results known $\mathrm{F}$ arithmetic is equal to 1.511 , sig of 0.224 while $F_{\text {table }}=4.03$ with $95 \%$ confidence level. Thus $F_{\text {count }}$ is smaller than $F_{\text {table }}$ (5.103> 2.70) meaning taht working mother parenting practice has no effect to social development.

Table 6. Model summary of working mother parenting practice and child's social development

\begin{tabular}{lrrrr}
\hline Model & $\mathrm{R}$ & $\begin{array}{c}\mathrm{R} \\
\text { Square }\end{array}$ & $\begin{array}{c}\text { Adjusted R } \\
\text { Square }\end{array}$ & $\begin{array}{l}\text { Std. Error of } \\
\text { the Estimate }\end{array}$ \\
\hline 1 & $.168^{\mathrm{a}}$ & .028 & .010 & 6.663 \\
\hline
\end{tabular}

Table 7. Anova of working mother parenting practice and child's social development

\begin{tabular}{|c|c|c|c|c|c|c|}
\hline \multicolumn{2}{|c|}{ Model } & \multicolumn{2}{|l|}{ Sum of } & \multicolumn{2}{|l|}{ Mean } & \multirow{2}{*}{$\frac{\text { Sig. }}{.224}$} \\
\hline 1 & $\begin{array}{l}\text { Regres } \\
\text { sion }\end{array}$ & 67.096 & 1 & 67.096 & $\begin{array}{r}1.5 \\
11\end{array}$ & \\
\hline & $\begin{array}{l}\text { Residu } \\
\text { al }\end{array}$ & 2308.552 & 52 & 44.395 & & \\
\hline & Total & 2375.648 & 53 & & & \\
\hline
\end{tabular}

\section{DISCUSSION}

The results of the correlation is "there is no significant relationship between working mother parenting practice and children social development aged 5-6 years in Purbalingga District". This is shown by very low regression coefficients and also negative value, or not unidirectional. This means that if the working mother parenting practice has increased, then the social development of children will decrease. Similarly vice versa, if the mother care work decreased, then the social development of children will increase. In this study, the smallest scores of working mother parenting practice indicated the better the parenting applied.

The results showed that working mother parenting practice was not significantly correlated with social development of children aged 5-6 years. The results of this study are similar with studies which explains that there is no significant difference between maternal care working with unemployed mothers (Almani, Abro and Mugheri, 2012). Despite working mother having less interaction time with children than mothers who are not working, but they are able to balance their role of being a mother and becoming a career woman.

The job's view of the mother makes a mother unable to run care optimally so that the child's social development has to be improved. Other factors as explained that parenting cooperation in the family between father and mother in carrying out their respective roles on parenting affect more than the relationship between child and mother only (Mangelsdorf, Laxman, and Jessee, 2011). Than just a mother doing good parenting, cooperation in parenting or coparenting is the extent to which the parents' efforts to support each other (Van Egeren \& Hawkins, 2004). That is, not only mothers who influence the social development of children, but the nurture of both parents who give more influence on the social development of children.

A little bit of research explaining how mom's work can predict the nurture she is implementing (Chang and Kim 2016). According to the results of this research analysis based on the influence of the type of mother's work with the development of children shows that the type of mother's work has no significant effect on the social development of children. Another study explains that mothers who earn satisfaction in work apply good warmth and care to their children (Rhee and Doh, 2007). That is, the type of work that mothers have does not become a significant predictor in predicting the nurture it implements.

\section{CONCLUSION}

Careful working mother care especially in Purbalingga district is important. This illustrates that 
the care of a working mother is not a significant factor that affects the good or not of social development of children. It can also change the public's view that children who behave badly are not only due to lack of attention or interaction with a mother. Parent co-operation in parenting is much more important than just mother-child relationships in building good social development.

This study only investigated the contribution of mother's age and child gender differences in parenting and child development relationships. Future research can be more detailed to see the contribution of other factors. The number of small respondents became a deficiency in this study. Future research in discussing similar problems can get more respondents and generalize the findings better. However, this research effort adds to the knowledge of how the influence of maternal care works against the social development of children aged 5-6 years.

\section{REFERENCES}

[1] Ahola, D. dan Kovacik, A. (2007). Observing and understanding child development: A child study manual. USA: Cengage Learning.

[2] Almani A. S., Abro A., dan Mugheri R. A. Study of the effects of working mothers on the development of children in pakistan. (2012). International Journal of Humanities and social Science. 2(11), 164-171.

[3] Badan Pusat Statistik Kabupaten Purbalingga. (2017). Statistik Daerah Kabupaten Purbalingga.

[4] Badan Pusat Statistik Provinsi Jawa Tengah. (2016). Direktori industri manufaktur besar sedang provinsi jawa tengah. Jawa Tengah: CV Pelita

[5] Berns, R. A. (2011). Child, family, school, community socialization and support. USA: Cengage Learning.

[6] Blazevi, I. (2016). Family, peer and school influence on children's social development. World Journal of Education, 6(2), 42-49. https://doi.org/10.5430/wje.v6n2p42.

[7] Brooks, J. (2011). The process of parenting. (Terjemahan Rahmat Fajar). Yogyakarta: Pustaka pelajar.

[8] Carlo, G., McGinley, M., Hayes, R., Batenhorst, C, \& Wilkinson, J. (2007). Parenting styles or practices? parenting, sympathy, and prosocial behaviors among adolescents. The Joumal of Genetic Psychology: Re- search and Theory on Human Development, 168, 147-176. doi: 10.3200/ GNTP.168.2.147-176.

[9] Chang Y. E dan Kim H. J. (2016). The relationship between job-role quality and parenting behaviour among employed mothers in korea. Journal of Comparative Family Studies. Vol (47), 527-548.
[10] Endedijk H. M., Cilessen A. H. N., Cox R. E. A., Bekkering H., dan Humnius A. (2014). The role of child characteristics and peer experiences in the development of peer cooperation. Social Development. 1-20. doi: 10.1111/sode. 12106

[11] Geoffrey, L. Brown; Brent A. Mcbride, Kelly K. Bost (2011) "Parental involvement, child temperament, and parents' work hours: Journal of Applied Developmental Psychology, 32(6), 3130322

[12] Hurlock, E. B. (1978). Perkembangan anak (jilid 1).(Terjemahan Meitasari Tjandrasa dan Muslichah Zaekasih).Jakarta: Penerbit Erlangga.

[13] Mangelsdorf, S. C, Laxman, D. J., \& Jessee, A. (2011). Coparenting in two-parent nuclear fam1ilies. In J. P. McHale \& K. M. Lindahl (Eds.), Coparenting: A conceptual and clinical examination of family system (pp. 39-59). Washington, DC: American Psychological Association, doi: 10.1037/12328-002.

[14] Marion, M. (2015).Guidance of young children( $9^{\wedge}$ th ed). USA: Pearson Inc.

[15] Marion, M. (2015).Guidance of young children( $9^{\wedge}$ th ed). USA: Pearson Inc.

[16] McKie, L. dan Callan, S.(2012). Understanding families: A global introduction. Sage Publication Ltd:UK.

[17] Mensah, M. K., \& Luranchie, A. (2013). Influence of parenting styles on the social development of children. Academic Journal of Interdisciplinary Studies MCSER, 2(3), 123130. https://doi.org/10.5901/ajis.2013.v2n3p123.

[18] Papalia D. E., Ods S. W, dan Feldman R. D. (2008). Human development. Amerika: McGraw Hill

[19] Parke, R. D dan Stewart, A. C. 2010. Social Development. USA: John Wiley \& Sons, Inc.

[20] Rhee, S. H., and Doh, H. S. (2007). Job satisfaction and parenting behavior of working mothers and children's problem behavior. Korean Journal o f Child Studies, 28(5), 269284.

[21] Santrock, J. W. (2007). Perkembangan anak.(Edisi ketujuh). (Terjemahan Mila Rachmawati dan Anna Kuswanti). Jakarta: Erlangga.

[22] Scrimgeour, M. B., Blandón, A. Y., Stifter, C. A., \& Buss, K. A. (2013). Cooperative Coparenting Moderates the Association Between Parenting Practices and Children' s Prosocial Behavior, 27(3), 506-511.

[23] Shpancer, N., Melick, K. M., Spivey, A. T. (2006). Quality of care attributions to employed versus stay at home mothers quality of care attributions to employed versus stay at home mothers. Early Child Development and Care, 4430(June) 183-193. https://doi.org/10.1080/03004430500039531.

[24] Spinrad, T. L., Eisenberg, N., Gaertner, B., Popp, T., Smith, C. L., Kupfer, A., et al. (2007). Relations of maternal socialization and toddlers effortful control to children's adjustment and social competence. Developmental Psychology, 
43, 1170-1186. http://dx.doi.org/10.1037/00121649.43.5.1170

[25] Stacia V. dan Gunanto E.Y.A. (2014). Profile industri bulu mata dan rambut palsu di kabupaten purbalingga. Diponegoro Journal of Economic. 3(1), 1-10.

[26] Sultana, A. M., \& Noor, Z. (2012). Mothers ' perception on the impact of employment on their children: Working and non-working mothers. International Journal of Social Science, 2(March), 113-131.
[27] Sultana, A. M., Nor, S., Binti, M., \& Suhaili, S. (2013). Parenting styles and satisfaction among working women in Kedah , Malaysia. Asian Journal of Humanities and Social Studies, 1(3), $136-141$.

[28] Van Egeren, L. A., \& Hawkins, D. P. (2004). Coming to terms with coparenting: Implications of definition and measurement. Joumal of Adult Measurement, 11, 165-178. doi: 10680667/04/0700-0165/0 